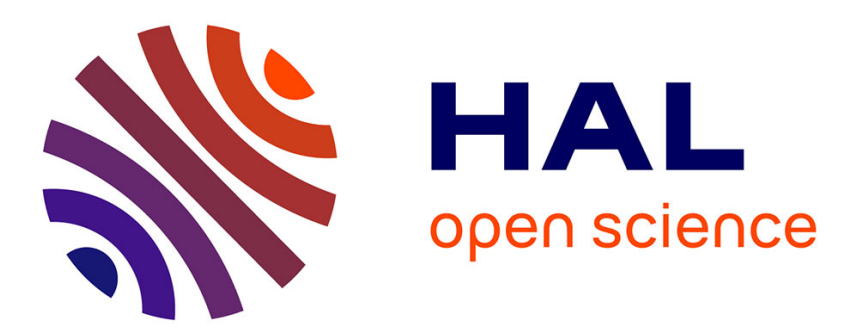

\title{
Reassessing the age of Karpathos ophiolite (Dodecanese, Greece): consequences for Aegean correlations and Neotethys evolution
}

\author{
Fabrice Cordey, Frédéric Quillévéré
}

\section{- To cite this version:}

Fabrice Cordey, Frédéric Quillévéré. Reassessing the age of Karpathos ophiolite (Dodecanese, Greece): consequences for Aegean correlations and Neotethys evolution. Geological Magazine, 2020, 157, pp.263-274. 10.1017/S0016756819000657 . hal-02266465

\section{HAL Id: hal-02266465 \\ https://hal.science/hal-02266465}

Submitted on 30 Jun 2021

HAL is a multi-disciplinary open access archive for the deposit and dissemination of scientific research documents, whether they are published or not. The documents may come from teaching and research institutions in France or abroad, or from public or private research centers.
L'archive ouverte pluridisciplinaire HAL, est destinée au dépôt et à la diffusion de documents scientifiques de niveau recherche, publiés ou non, émanant des établissements d'enseignement et de recherche français ou étrangers, des laboratoires publics ou privés. 
3 Title: Reassessing the age of Karpathos ophiolite (Dodecanese, Greece): consequences for 4 Aegean correlations and Neotethys evolution.

5

6 Category: Original Article

7

8 Authors : FABRICE CORDEY, FRÉDÉRIC QUILLÉVÉRÉ

9

Université de Lyon, Université Claude Bernard Lyon 1, Laboratoire de Géologie de Lyon

Terre Planètes Environnement LGLTPE, CNRS-UMR 5276, Bd du 11 Novembre 1918, 69622 Villeurbanne, France

13

Short title: Age of Karpathos ophiolite

15

Corresponding author: fabrice.cordey@univ-lyon1.fr

17

18 
Abstract

While the Neogene history of the Eastern Mediterranean region is now fairly well understood, our knowledge of older regional paleogeographies is less accurate, especially the positions of blocks and nappes constituting the Aegean Islands prior to the Cenozoic. Our study focuses on the ophiolite exposed on the island of Karpathos (Dodecanese), which is located in the Aegean fore-arc at a pivotal position between the 'western' and 'eastern' ophiolites of the Mediterranean region and where conflicting Late Jurassic and Late Cretaceous ages have led to diverging tectonic and paleogeographic interpretations. To test these ages, we targeted the radiolarian cherts that depositionally overlie the ophiolite and extracted diagnostic radiolarian assemblages of Aptian ( 125-113 Ma), early-middle Albian ( 113-105 Ma), and Turonian ( 93.9-89.8 Ma) ages. These results suggest that previous Late Cretaceous K-Ar isotopic ages (from $95.3 \pm 4.2 \mathrm{Ma}$ to $81.2 \pm 1.6 \mathrm{Ma}$ ) may have been reset by Late Cretaceous metamorphism or affected by argon loss. Overall, the new Early Cretaceous ages show that the Karpathos ophiolite should not be correlated with the Pindos Nappes of Greece or the ophiolites of Cyprus or Syria but rather with the Lycian Nappes of Turkey and their root located in the Izmir-Ankara-Erzincan Suture Zone. Therefore, the Karpathos ophiolite represents a remnant of the Northern Neotethys, not the Pindos Ocean or the proto-Eastern Mediterranean Basin.

Keywords: ophiolite, radiolarite, Radiolaria, Cretaceous, Karpathos, Aegean fore-arc, Neotethys. 


\section{Introduction}

Present-day convergent margins are often characterized by the occurrence of ophiolites along the upper plate(s) in a large variety of settings related to terrane accretion processes (see Dilek \& Furnes, 2014, and references therein). This study focuses on the island of Karpathos (Dodecanese, Greece), which belongs to the Aegean fore-arc (Figure 1) and is located at the junction between two important ophiolite domains of the Mediterranean region: the western region (Dinarides, Hellenides) and the eastern region (Taurides, Cyprus, Syria) (Robertson, 2002). Although the Neogene history of the Eastern Mediterranean region is fairly well understood following a very large number of studies and the application of powerful tools such as high-resolution seismic tomography (Royden \& Faccenna, 2018, and references therein), our knowledge of older regional paleogeographies is less accurate. In the Aegean Sea, the origin of scattered blocks and nappes constituting the Cyclades, Crete and the Dodecanese is not well understood. In particular, there are some difficulties in establishing precise geological correlations between these islands and the surrounding continental margins (Roche et al. 2018).

Due to its "pivotal” position between the ophiolite regions of Greece and Turkey, Karpathos has attracted significant geological attention for more than a century (see Appendix “Pioneering studies on Karpathos”, online Supplementary Material at http://journals.cambridge.org/geo), but diverging interpretations about the age of the ophiolite have led to conflicting views: while K-Ar geochronology documented Late Cretaceous isotopic ages (Koepke, Kreuzer \& Seidel, 1985; Hatzipanagiotou, 1991; Koepke, Seidel \& Kreuzer, 2002), the sedimentary rocks overlying the ophiolite were considered to be early Early Cretaceous based on calpionellids, suggesting that the ophiolite could be as old as Late Jurassic (Davidson-Monett, 1974; Aubouin, Bonneau \& Davidson, 1976). These two distinct ages led to very different paleogeographic scenarios: the Karpathos ophiolite has been 
interpreted as a remnant of the Pindos Ocean (Aubouin, Bonneau \& Davidson, 1976), the Northern Neotethys (Robertson, 2002), or the Southern Neotethys due to age and petrological affinities with Late Cretaceous ophiolites of Turkey, Syria and Oman (Koepke, Seidel \& Kreuzer, 2002).

Since no modern radiolarian study has ever been undertaken on the island, we have revisited Karpathos and reassessed the potential of its supra-ophiolitic sedimentary strata, with three major objectives: 1) to solve this chronological conundrum by focusing on radiolarian cherts, 2) to improve the correlations between Karpathos and the surrounding Mediterranean ophiolites (Greece, Crete, Rhodes, Turkey), and 3) to develop a better understanding of Neotethys paleogeography and tectonics in the Aegean region.

\section{Geological setting}

\section{2.a. The Xindothio Unit}

The Karpathos ophiolite forms relatively small exposures (Figure 2a-c) of mainly serpentinized peridotite with minor occurrences of gabbro and dolerite dykes ('dismembered' type after Coleman, 1977). Early geological studies provided some preliminary descriptions of the magmatic rocks and associated sedimentary strata (de Stefani, Forsyth Major \& Barbey, 1895; Martelli, 1916; Christodoulou 1960; Aubouin \& Dercourt, 1970; online Supplementary Material at http://journals.cambridge.org/geo). Later, geological mapping demonstrated that these rocks lie within tectonic slices at the top of the nappe pile exposed in the central part of the island and belong to a tectono-stratigraphic succession described as the 'Xindothio Unit' (Davidson-Monett, 1974; Aubouin, Bonneau \& Davidson, 1976; Hatzipanagiotou, 1987). The Xindothio Unit overlies the Kalilimni Unit, a Jurassic to Eocene parautochthonous carbonate platform (Figure 2a), and comprises eight subunits from base to top (Figure 3a): ammonitebearing marl, belemnites-bearing sandstone, platy limestone with filaments (Halobia), grey 
platy limestone, mafic and ultramafic rocks (serpentinite, gabbro, dolerite), red radiolarite and pink microcrystalline limestone, platy green limestone, fine-grained limestone and siliceous beds. The base of the Xindothio Unit has been dated as early Late Triassic (Carnian) with ammonites (Tropites subbullatus; Aubouin, Bonneau \& Davidson, 1976), while the top is

Campanian-Maastrichtian based on planktonic foraminifera (Globotruncana stuarti, G. stuartiformis, and G. contusa; Aubouin, Bonneau \& Davidson, 1976).

Mafic and ultramafic rocks are commonly found in tectonic contact with the underlying units, whereas the radiolarites depositionally overlie the ophiolite at many locations in the Lastos and Menetes areas (Davidson-Monett, 1974; Aubouin, Bonneau \& Davidson, 1976; Hatzipanagiotou, 1987, 1988) (Figures 2a-c, 3a). The depositional nature of this contact is supported by good lateral continuity of the radiolarites which show no significant deformation. The rarity of basalts and the direct contact between the magmatic rocks and the radiolarites suggest that the Karpathos ophiolite formed by relatively slow spreading. Near the contact, red chert beds are 5-15 cm thick, whereas these beds are less abundant upsection and crop out as thin continuous layers or chert nodules. Overall, the radiolarite-pink limestone subunit is approximately 40 m thick (Figures 3a, 4).

\section{2.b. Previous ages of the ophiolite and overlying strata}

Vinassa de Regny (1901) provided the first study of Karpathos radiolarians, which he observed within 'phtanites’ (black cherts) and ‘argillaceous jaspers' (red-maroon cherts) collected in the Lastos area (Figure 2a, b). This pioneering work led to the description of fiftyeight radiolarian morphotypes (online Supplementary Material at http://journals.cambridge.org/geo), although most of the identified genera are now classified as nomen dubium (O’Dogherty et al. 2009). In the light of current radiolarian taxonomy, some of the forms illustrated by Vinassa de Regny (1901) resemble the modern genera Archaeospongoprunum, Hiscocapsa, Paronaella, Pseudoeucyrtis, Pseudodictyomitra, and 
Triactoma, but their occurrence is difficult to confirm given the discrepancies between 1900s drawings and present-day taxonomy based on three-dimensional scanning electron microscope (SEM) observations. Vinassa de Regny (1901) suggested that the faunal assemblage was possibly Late Cretaceous, although this age determination was tentative due to the absence of radiolarian biozonation at the time. Later, an age determination was obtained on the radiolarite-pink limestone subunit with one calpionellid assemblage (Davidson-Monett, 1974; Aubouin, Bonneau \& Davidson, 1976) and was assigned to the middle-late Berriasian (145-139.8 Ma; Cohen et al. 2013, updated 2018). Consequently, these authors suggested that the ophiolite could be as old as Late Jurassic.

The K-Ar isotopic ages obtained later on the magmatic rocks (hornblende grains extracted from intrusive dolerites) are much younger than the overlying sedimentary strata (Table 1; Koepke, Kreuzer \& Seidel, 1985; Hatzipanagiotou, 1991; Koepke, Seidel \& Kreuzer, 2002). In Lastos, two ages range between 84.7 and 79.6 Ma, encompassing the middle Santonian-middle Campanian interval (Cohen et al. 2013, updated 2018). In Menetes, the isotopic ages range between 99.5 and $88.4 \mathrm{Ma}$, corresponding to the middle Cenomanian-middle Coniacian interval.

\section{Studied sections and methods}

Our study focused on identifying the contact between mafic/ultramafic rocks and the overlying radiolarian cherts in order to select a few localities for sampling. This contact is exposed in the high valley of Lastos on the eastern flank of Mount Kalilimni (Figures 2b, 5) and near the village of Menetes on the southern flank of Mount Homali (Figure 2c). To maximize the quality of the faunas, we selected a variety of radiolarian samples in accordance 
with specific field techniques previously applied to suture zones and fore-arc belts (Cordey \& Krauss, 1990; Cordey \& Cornée, 2009). Radiolarians were then extracted by repetitive leaching of samples with low-concentration hydrofluoric acid (HF) and then hand-picked and mounted on aluminium stubs for SEM observation and taxonomical identifications (Tabletop SEM Phenom ProX, University of Lyon).

In Lastos, our samples were collected from two sections:

1/ section 'North Lastos road' (Figure 2b; Table 2). This section is composed of an outcrop of serpentinites depositionally overlain by radiolarian cherts and pink limestones. KAL01 was collected from a red radiolarite bed situated $30 \mathrm{~cm}$ above the serpentinite body (Figure 3b). Similar stratigraphic contacts between serpentinites and radiolarites are visible at several locations along the North Lastos road (Figures 2b, 5b, c).

2/ section 'Hill 730 m’ (Figure 2b, Table 2). This section was previously described by Davidson-Monett (1974) and Aubouin, Bonneau \& Davidson (1976) under the name 'section of hill 738 m’ (Figures 3b, 4) and renamed to follow the revised topography available on the Karpathos-Kasos map sheet (Psimenos et al. 2017). Sample KAL02 is from a bed of red radiolarian chert at the base of the radiolarite-pink limestone subunit located just above the contact with gabbros and serpentinites (Figures 3b, 5a, 5e). Sample KAL03 is from a red nodular radiolarian chert bed and was collected at the top of the radiolarite-pink limestone subunit (Figures 3b, 5d).

Near Menetes, our sample locality KAM01 (Figure 2c, Table 2) is from a bed of radiolarite interbedded with pink limestones, $150 \mathrm{~m}$ to the south of a well-exposed serpentinite outcrop at the foot of Mount Homali (Figure 3b).

\section{Results}


174 The preservation of radiolarians extracted from our chert samples varies from moderate to 175 good at both the Lastos and Menetes locations. All of the radiolarian taxa and assemblages 176 identified in the samples are listed in Table 3. Morphotypes with biochronological 177 significance are illustrated in Figure 6.

KAL01 comprises sixteen identified taxa (Table 3). Among them, an assemblage composed of Archaeodictyomitra gracilis, Crucella euganea, Crucella messinae, Hiscocapsa asseni, Hiscocapsa grutterinki and Pseudodictyomitra lodogaensis corresponds to the unitary associations zones (UAZ) 4-9 of O’Dogherty (1994) of early-late Aptian age. Other Early Cretaceous species include Cenodiscaella sphaeroconus, Homoeoparonaella sp. cf. speciosa, Mesosaturnalis sp., Paronaella sp., Pseudocrucella sp. aff. kubischa, Pseudoeucyrtis(?) fusus, Stichomitra communis, Ultranapora sp. cf. durhami and Xitus sp. aff. spicularius. Among them, Stichomitra communis is known from the Aptian-Turonian interval (UAZ 42-46; Goričan, 1994). We interpret the morphotype illustrated in Figure $6\left(n^{\circ} 14\right)$ as Dictyomitra montisserei, which we consider to have a slightly longer age range than previously proposed (UAZ 10-20 of Albian-Turonian age; O’Dogherty, 1994).

KAL02 is composed of eight radiolarian taxa (Table 3). The co-occurrence of Crucella messinae, Cyclastrum satoi, Dactyliosphaera lepta, Hexapyramis sp. cf. precedis, Mesosaturnalis levis and Xitus spicularius points to UAZ 11-12 of early-middle Albian age 194 (O’Dogherty, 1994). Some other taxa have longer age ranges, such as Alievium sp. (Bajocian-Maastrichtian, O’Dogherty et al. 2009) and Obeliscoites sp. cf. perspicuus (UAZ 1-19, Barremian-Cenomanian; O’Dogherty, 1994). 
KAL03 comprises ten radiolarian taxa (Table 3). Alievum sp. cf. superbum, Crucella cachensis, and Dictyomitra napaensis are known as Turonian (Pessagno, 1976). Other taxa have been found to co-occur in Turonian biozones, such as Stichomitra communis (UAZ 42-48 of late Aptian-Turonian; Goričan, 1994), Dictyomitra montisserei (UAZ 10-20, Albian-Turonian; O’Dogherty, 1994), Pseudodictyomitra pseudomacrocephala (UAZ 10-21, Albian-Turonian; O’Dogherty, 1994), and Afens sp. (Turonian-Campanian; O’Dogherty et al. 2009).

KAM01 contains seven radiolarian taxa, including species reported from the biozonation of O’Dogherty (1994), such as Distylocapsa micropora (UAZ 10-18) and Thanarla brouweri (UAZ 1-12), corresponding to a middle Albian age. Other taxa are Archaeospongoprunum renaensis (Albian; Pessagno, 1977), Cenodiscaella tuberculatum (early Cenomanian-?early Turonian; Pessagno, 1977), Staurosphaeretta sp. (late Aptian-early Turonian; O’Dogherty et al. 2009), Pseudodictyomitra lodogaensis (UAZ 42-46, late Aptian-late Albian; Goričan, 1994), and Triactoma sp. (early Pliensbachian-late Turonian; O’Dogherty et al. 2009).

In summary, the radiolarian ages established for the radiolarite-pink limestone subunit of the Xindothio Unit are from base to top: early-late Aptian (KAL01; 125-113 Ma; Cohen et al. 2013, updated 2018), early-middle Albian (KAL02; 113-105 Ma), middle Albian (KAM01; 110-105 Ma), and Turonian (KAL03; 93.9-89.8 Ma) (Figure 3a, b).

\section{Discussion}

\section{5.a. Comparison with previous microfossil ages}


The three Aptian and Albian radiolarian ages ( 125-105 Ma) obtained at the base of the

223 radiolarite-pink limestone subunit at Lastos (KAL01, KAL02) and Menetes (KAM01) are significantly younger than the Berriasian age (145-139.8 Ma) previously reported from the same sequence (Davidson-Monett, 1974; Aubouin, Bonneau \& Davidson, 1976). A similar issue applied on Rhodes, where Danelian et al. (2001) established that Berriasian calpionellids from the Profitis Ilias succession had been misidentified. This situation could also be the case in Karpathos. Another hypothesis is that these calpionellids have been reworked. In any case, based on results obtained in three sections in two separate areas (Lastos and Menetes; Figure 3a, b), our data show that the radiolarites of the Xindothio Unit are not Berriasian but rather Aptian-Albian.

Our younger radiolarian assemblage is Turonian ( 93.9-89.8 Ma) and was obtained at the top of the radiolarite-pink limestone subunit (KAL03). Foraminifera of similar age were reported from the base of the platy limestone subunit (Davidson-Monett, 1974; Aubouin, Bonneau \& Davidson, 1976).

\section{5.b. Comparison with K-Ar isotopic ages}

K-Ar isotopic ages of Koepke, Seidel, \& Kreuzer (2002) are shown in Table 1. At Menetes, the age difference with the radiolarian data is minor, as the oldest isotopic age of $95.3 \pm 4.2$ Ma fits into the early Cenomanian (Cohen et al. 2013, updated 2018). At Lastos, the age difference is greater: while radiolarians near the contact are Aptian, the oldest isotopic age is middle Santonian (84.7 Ma, Table 1). To explain such a discrepancy, four hypotheses are considered below:

1/ Aptian-Albian radiolarians were reworked and redeposited in younger Late Cretaceous sediments. This process seems unlikely since the radiolarian assemblages do not show any unusual mixing of incompatible taxa (Table 3). These assemblages also document a coherent 
succession of upward-younging ages (Aptian > early-middle Albian > middle Albian > Turonian; Figure 3a). In addition, the Turonian ages obtained independently with planktonic foraminifera (Aubouin, Bonneau \& Davidson, 1976) and radiolarians (this study) near the contact between radiolarite-pink limestone and platy limestone subunits are both older than the K-Ar isotopic ages of Koepke, Seidel, \& Kreuzer (2002).

2/ The contact between mafic/ultramafic rocks and radiolarites is tectonic. However, this hypothesis is not consistent with our field observations or those of Davidson-Monett (1974), Aubouin, Bonneau \& Davidson (1976) and Hatzipanagiotou (1988). The Xindothio Unit is not an accretionary-type "broken formation” where subunits are chaotically juxtaposed. Instead, it shows good reproducibility of the stratigraphic contact between the magmatic rocks and the overlying radiolarian cherts, not only at Lastos but also at Menetes (Figure 2b, c). In addition, there is good lateral continuity of the contact as shown by the parallel bedding of the radiolarite-pink limestone subunit along strike (Figure 5b, c). One could argue that the Karpathos ophiolite is dismembered and that mafic and ultramafic rocks may not be of the same age as the overlying strata, but in a dismembered or mélange-type configuration, the radiolarian-bearing sedimentary matrix should be closely synchronous or younger than any such olistoliths, not older (Cordey, 1998).

3/ The Karpathos ophiolite has a longer age range than previously envisaged, i.e., spanning the Early-Late Cretaceous, more precisely the Aptian-Santonian (from 125-113 Ma to 84.7 $\mathrm{Ma}$ ), representing the interval between the radiolarites overlying the ophiolite and the oldest isotopic age in Lastos. In this case, the Xindothio radiolarites should be diachronous.

Considering the consistent Early Cretaceous ages from Lastos and Menetes areas (this study), as well as the relatively small volumes of mafic and ultramafic rocks exposed on the island (Figure 2a-c), we do not favour this hypothesis.

4/ Isotopic ages from Lastos have undergone some metamorphic overprint or are affected by argon loss. This is, to us, the most likely cause of the chronological discrepancy, as both 
phenomena can cause calculated K-Ar ages to be younger than the true ages of the dated material (McDougall \& Harrison, 1999). Similarly, it has been established that some of the youngest Cretan ophiolites underwent such overprinting during the Late Cretaceous (95 Ma; Koepke, Seidel \& Kreuzer, 2002). Other authors have also shown that some Cretan isotopic ages record the age of obduction rather than oceanic crust formation (Liati, Gebauer \& Fanning, 2004; Stampfli, Champod \& Vandelli, 2010). In Turkey, Ar-Ar isotopic ages of the metamorphic soles of the Lycian peridotites are mainly 92-90 Ma (Dilek et al. 1999), an age range that is similar to the $\mathrm{K}-\mathrm{Ar}$ isotopic ages on Karpathos. More recently, $\mathrm{U}-\mathrm{Pb}$ ages on zircons from the metamorphic sole of the Marmaris ophiolite (Lycian Nappes) have shown that their tectonic emplacement occurred between 100.4 Ma and 93.5 Ma (Cenomanian), suggesting an Early Cretaceous age for the ophiolite and the associated sedimentary rocks (Güngör et al. 2018). Unfortunately, previous geochronological studies carried out on Karpathos (Koepke, Kreuzer \& Seidel, 1985; Hatzipanagiotou, 1991; Koepke, Seidel \& Kreuzer, 2002) did not document the precise locations for the K-Ar samples or indicate whether the magmatic rocks were overlain by sedimentary strata, preventing comparative sampling of sections.

We do not know to what extent the discrepancy between biochronological and geochronological data observed on Karpathos is a localized problem or a larger issue concerning Mesozoic ophiolites. Some isotopic ages established on these ophiolites using KAr methods in the 1980s and 1990s probably need to be tested with more up-to-date methods such as Ar-Ar and/or U-Pb, as carried out by and Liati, Gebauer \& Fanning (2004) and Smith (2006), who obtained zircon ages on hornblendites and gabbros from Cretan ophiolites, and Parlak et al. (2013) who used hornblendes and zircons from ophiolites of the Tauride belt. 


\section{Eastern Mediterranean correlations and implications for Neotethys evolution}

Tectonic reconstructions of the Eastern Mediterranean region imply the southward migration

303 of the Aegean fore-arc relative to Eurasia since Eocene times, a result of the rollback of subducting African lithosphere (Zachariasse, Van Hinsbergen \& Fortuin, 2008; Jolivet et al. 2013). Prior to the Paleogene, the paleogeographic evolution of the region has been described by many authors at the scale of the Tethyan Realm (Robertson, 2002; Barrier \& Vrielynck, 2008; Menant et al. 2016; Barrier et al. 2018), but these descriptions lack precision for the islands of the Aegean Sea. Several hypotheses have been proposed for the Karpathos ophiolite: initially, it was correlated with the ophiolites of Crete, both of which were considered the easternmost remnants of the Pindos Nappes of continental Greece and the Peloponnese (Figures 1, 7; Aubouin, Bonneau \& Davidson, 1976; van Hinsbergen et al. 2005; Papanikolaou, 2013; Ersoy et al. 2014; Pantopoulos \& Zelilidis, 2014). Other authors have interpreted the Karpathos and Rhodes ophiolites as southwestward extensions of the Lycian Nappes exposed in southwestern Turkey (Figure 1; Robertson, 2002; Koepke, Seidel \& Kreuzer, 2002; van Hinsbergen et al. 2010). The ophiolites of Karpathos and Rhodes have also been associated with the Late Cretaceous ophiolites of Cyprus, Syria, and Oman (Koepke, Seidel \& Kreuzer, 2002), hence as potential remnants of a basin located to the south of Turkey, in a precursor position of the present-day Eastern Mediterranean Basin. In summary, these conflicting interpretations consider the Karpathos ophiolite as an element of the western Northern Neotethys (Pindos Zone), the central Northern Neotethys (Izmir-Ankara-Erzincan suture and Lycian Nappes), or the Southern Neotethys (Cyprus-Syria) (Figure 7).

A geological review of ophiolites exposed in the Aegean fore-arc (Figure 8a) shows that the ophiolite of Karpathos is younger than those of Crete, where $\mathrm{K}-\mathrm{Ar}$ isotopic ages range from 
160 to 140 Ma (Middle-Late Jurassic) (Koepke, Seidel \& Kreuzer, 2002; Liati, Gebauer \& Fanning, 2004). Notably, the youngest Cretan radiolarites are Late Jurassic in age (Stampfli, Champod \& Vandelli, 2010), similar to the Pindos radiolarites of continental Greece (De Wever \& Cordey, 1986). Another significant difference is that, on Karpathos, a shallow marine Upper Eocene conglomerate overlies the dismembered ophiolite together with the Mesozoic limestones (Kalilimni Unit) (Figures 2b, 5f), showing that these units were already tectonically assembled while flysch deposition was still continuing in the Pindos Basin farther west.

Our results indicate that the closest chronological and petrological similarities with the ophiolite of Karpathos are found in southwestern Turkey, more specifically within the Lycian Nappes (de Graciansky, 1967; Collins \& Robertson, 1997, 2003; Dilek et al. 1999; Robertson, 2002). In the Lycian Mélange, Danelian et al. (2006) documented Jurassic and Early

Cretaceous radiolarian cherts. In the Marmaris ophiolite, the youngest sediments associated with the ophiolite are pre-Cenomanian (Güngör et al. 2018).

Many authors have established a link between the Lycian Nappes and the Izmir-Ankara-Erzincan Suture Zone situated to the north of the Menderes metamorphic complex (Figure 8a) (Robertson \& Pickett, 2000; Okay et al. 2001; Collins \& Robertson, 2003; Robertson et al. 2004). The Izmir-Ankara-Erzincan Suture Zone is itself considered a remnant of the Northern Neotethyan Ocean (Danelian et al. 2006) and records a long history of radiolarite accumulation. In the Central Sakarya Zone, the Dağküplü Mélange includes several slices of mid-ocean ridge metabasalts (MORB-type) that alternate with radiolarites dated to the Middle-Late Jurassic (Bathonian-Tithonian), Early Cretaceous (Hauterivian-Aptian) and early Late Cretaceous (Cenomanian) (Göncüoğlu et al. 2000, 2001). Farther east in the Ankara Mélange, blocks of radiolarite associated with gabbro and 
pink micritic limestone are dated as Late Triassic, Early Jurassic, Late Jurassic and Early

353 Cretaceous, including Aptian and Albian strata such as on Karpathos (Bragin \& Tekin, 1996).

As in the Dağküplü Mélange, the youngest radiolarites of the Ankara Mélange are

Cenomanian (Bragin \& Tekin, 1996). Previous authors noted great similarities in both petrography and trace elements between Karpathos and Rhodes mafic and ultramafic rocks and those of western Turkey, emphasizing the depleted nature of the peridotites and the geochemistry of dykes that are typical of supra-subduction zone ophiolites (Koepke, Seidel \& Kreuzer, 2002).

Farther south in the Antalya Complex, MOR-type (mid-ocean ridge) volcanic rocks are overlain by Late Jurassic-Early Cretaceous radiolarian cherts (Robertson \& Woodcock, 1982; Yilmaz, 1984; Robertson, 2002), partly coeval with Karpathos radiolarites. However, the Antalya Complex records a distinct geological history and tectonic setting of an oceanic domain located to the south of the Tauride carbonate platform (Figure 7; Barrier \& Vrielynck, 2008; Robertson, Parlak \& Ustaömer, 2012; Barrier et al. 2018).

The ophiolites of Karpathos and Rhodes have also been correlated with the Late Cretaceous ophiolites of Cyprus, Syria, and Oman (Koepke, Seidel \& Kreuzer, 2002) and hence interpreted as potential remnants of the Southern Neotethys (Figure 7). However, this hypothesis is not supported by the tectonic interpretations that imply that the emplacement of the Karpathos and Rhodes ophiolites proceeded southward during the closure of a basin located to the north of Turkey (van Hinsbergen et al. 2010; Schettino \& Turco, 2011).

In summary, the comparison of these various interpretations suggests that the Karpathos ophiolite originated in the central Northern Neotethys (Figure 7; Dilek et al. 1999; Robertson, 2002; Barrier \& Vrielynck, 2008; Menant et al. 2016; Barrier et al. 2018) and is linked to the 
Lycian Nappes and their root, the Izmir-Ankara-Erzincan Suture Zone. A slight difference

379 lies in the age of the youngest radiolarites between these units: while Karpathos radiolarites are Aptian-Albian (125-100.5 Ma; Cohen et al. 2013, updated 2018), the youngest radiolarites of the Lycian Nappes and the Izmir-Ankara-Erzincan Suture Zone are consistently Cenomanian (100.5-93.9 Ma). In addition, the age range represented by the ophiolite is much shorter on Karpathos (late Early Cretaceous). This suggests that the Karpathos ophiolite may be a remnant of a short-lived segment of the Northern Neotethys that was originally located in the westernmost part of the Izmir-Ankara-Erzincan Suture Zone (Figures 7, 8). The convergence and closure of the Northern Neotethys during the Paleogene then led to the thrusting of ophiolite-bearing tectonic slices over the Karpathos parautochthonous carbonate platform, similar to the Lycian Nappes over Rhodes (Figure 8b). Eventually, the southward movement of the Aegean arc during the Neogene distorted the original Paleogene configuration, separating Karpathos farther from the ancient Izmir-Ankara-Erzincan root zone.

\section{Conclusions}

Our study documents the occurrence of Early Cretaceous radiolarians in sedimentary rocks overlying mafic and ultramafic rocks on the island of Karpathos, with the following implications:

- The older radiolarian assemblage provides a minimum Aptian age ( 125-113 Ma) for the ophiolite, while the younger assemblage indicates that the top of the radiolarite-pink limestone subunit is Turonian ( 93.9-89.8 Ma). The Aptian and Albian radiolarian ages raise

402 questions regarding the accuracy of a Berriasian age obtained previously from a single calpionellid assemblage in the same subunit. 
- The oldest radiolarian ages (late Early Cretaceous) are significantly older than those proposed for the ophiolite using K-Ar geochronology (Late Cretaceous, from $95.3 \pm 4.2$ Ma to $81.2 \pm 1.6 \mathrm{Ma}$ ), suggesting that these isotopic ages may have been reset by Late Cretaceous metamorphism, or were affected by argon loss.

- The Karpathos ophiolite should not be associated with the Pindos Nappes or the ophiolites of Cyprus or Syria but rather with the Lycian Nappes and their root located in the Izmir-Ankara-Erzincan Suture Zone, possibly representing the westernmost part of this structure. Consequently, the ophiolite of Karpathos is likely to be a remnant of the Northern Neotethys, not of the Pindos Ocean or the proto-Eastern Mediterranean Basin.

- From an analytical viewpoint, our study suggests that previous K-Ar isotopic ages obtained from the ophiolites of the Mediterranean region should be revised with more recent and accurate methods (Ar-Ar, U-Pb), particularly for geological units that have been affected by syn- or post-emplacement metamorphism and deformation.

\section{Acknowledgements}

This study was funded by the Laboratory of Geology of Lyon (LGLTPE, UMR5276) and by the National Research programme Tellus-INTERRVIE of the French CNRS-INSU (Centre National de la Recherche Scientifique - Institut National des Sciences de l'Univers). The authors are grateful to the editor Peter D. Clift as well as Alastair H.F. Robertson and an anonymous reviewer for their very constructive comments concerning previous versions of the manuscript. Geological mapping by John Davidson in the 1970s was a valuable source of information. The authors also wish to thank Jean-Jacques Cornée, Sébastien Joannin (University of Montpellier) and Pierre Moissette (University of Athens) for our discussions on the geology of Karpathos and the Aegean fore-arc. 
None

432

433

Supplementary Material

434

435

Appendix "Pioneering studies on Karpathos" available online at

http://journals.cambridge.org/geo

436

437

438

\section{References}

439

440

441

442

443

444

445

446

447

448

449

450

451

452

453

454

455

Aubouin, J. \& Dercourt, J. 1970. Sur la géologie de l’Egée: regard sur le Dodécanèse méridional (Kasos, Karpathos, Rhodes). Bulletin de la Société Géologique de France 7 (12), 455-472.

Aubouin, J., BonneAu, M. \& DAVIDSOn, J. 1976. Contribution à la géologie de l’arc égéen:

l'île de Karpathos. Bulletin de la Société Géologique de France 7 (18), 385-401.

BARrier, E. \& VRIElynCK, B. 2008. Palaeotectonic maps of the Middle East. Commission for the Geological Map of the World, Paris.

BArRier, E., VRielynck, B., Brouillet, J. F. , Brunet, M. F. 2018. Paleotectonic reconstruction of the Central Tethyan Realm. Tectonono-Sedimentary-Palinspastic maps from Late Permian to Pliocene. Commission for the Geological Map of the World, Paris.

Bornovas, I. \& RonTOGIANNI-TSIABAOU, T. 1983. Geological map of Greece. Institute of Geology and Mineral exploration, scale 1:500,000. 
469

470

471

472

473

474

475

476

477 CoRdey, F. 1998. Radiolaires des complexes d'accrétion cordillérains. Geological Survey of 478 479

BRAgin, N. Y. \& TeKIN, U. K. 1996. Age of radiolarian-chert blocks from the Senonian

Ophiolitic Mélange (Ankara, Turkey). The Island Arc 5, 114-122.

CHRIstodoulOU, G. 1960. Geologische und mikropaläontologische untersuchungen auf der insel Karpathos (Dodekanes). Palaeontographica, Abteilung A, 115 (1-6), 1-143.

Christodoulou, G. 1968. Karpathos map sheet. Geological map of Greece. Institute for geology and subsurface research, Athens.

Cohen, K.M., Finney, S.C., GibBARD, P.L. \& FAn, J.-X. 2013 (updated 2018). The ICS International Chronostratigraphic Chart. Episodes 36 (3), 199-204.

Coleman, R.G. 1977. Ophiolites-Ancient Oceanic Lithosphere? Springer, Berlin, 229 pp.

Collins, A.S., RoBERTSOn, A.H.F. 1997. Lycian melange, southwestern Turkey: an emplaced Late Cretaceous accretionary complex. Geology 25, 25- 258.

Collins, A. S. \& Robertson, A. H. F. 2003. Kinematic evidence for Late Mesozoic-Miocene emplacement of the Lycian Allochthon over the Western Anatolide Belt. Geological Journal 38, 295- 310 .

Canada Bulletin 509, 1-210. 
CoRdey, F. \& CoRnEe, J.-J. 2009. New radiolarian assemblages from La Désirade Island basement complex (Guadeloupe, Lesser Antilles Arc) and Caribbean tectonic implications, Bulletin de la Société Géologique de France 180 (5), 399-409.

Cordey, F. \& Krauss, P. 1990. A field technique for identifying and dating radiolaria applied to British Columbia and Yukon. Geological Survey of Canada Paper 90-1E, $127-129$.

Danelian, T., Bonneau, M., Cadet, J.-P., Poisson, A. \& VRielynck, B. 2001.

Palaeoceanographic implications of new and revised bio-chronostratigraphic constraints from the Profitis Ilias Unit (Rhodes, Greece). Bulletin of the Geological Society of Greece 34 (2), $619-625$.

\section{Danelian, T., Robertson, A.H.F., Collins, A.S. \& Poisson, A. 2006. Biochronology of} Jurassic and Early Cretaceous radiolarites from the Lycian Mélange (SW Turkey) and implications for the evolution of the Northern Neotethyan ocean. Geological Society of London 260, 229-236.

DAVIDSON-MonetT, J. 1974. Contribution à l'étude géologique de l'arc égéen: l'île de Karpathos (Dodécanèse Méridional, Grèce). Thèse $3^{\text {ème }}$ cycle, University Paris 6, 150 p.

DE GRACIANSKY, P.C. 1967. Existence d'une nappe ophiolitique à l'extrémité occidentale de la chaîne sud-anatolienne: relations avec les autres unités charriées et avec les terrains autochtones (Province de Muğla, Turquie). Comptes Rendus Académie Sciences Paris 264, 2876-2879. 
de Stefani, C., Forsyth Major, C.J. \& Barbey, W. 1895. Aperçu géologique et paléontologique de l'Ile de Karpathos. In Karpathos, étude géologique, paléontologique et botanique (eds. G. Bridel et Cie, Lausanne), 153-164.

DE WeVER, P. \& CoRdey, F. 1986. Datation par les radiolaires de la formation des radiolarites s.s. de la série du Pinde-Olonos (Grèce) : Bajocian(?) - Tithonique. Marine Micropaleontology 11, 113-127.

DiLEK, Y., \& FurNES, H. 2014. Ophiolites and their origins. Elements 10, n 2, 93-100.

DileK, Y., ThY, P., HACKeR, B. \& GRUNDVIG, S. 1999. Structure and petrology of Tauride ophiolites and mafic dyke intrusions (Turkey): implications for the Neotethyan ocean. Geological Society of America Bulletin 111, 1192-1216.

Ersoy, E.Y., Cemen, I., Helvaci, C. \& BilloR, Z. 2014. Tectono-stratigraphy of the Neogene basins in Western Turkey: Implications for tectonic evolution of the Aegean Extended Region. Tectonophysics 635, 33-58.

GARFUNKEL, Z. 2004. Origin of the Eastern Mediterranean basin: a reevaluation.

Tectonophysics 391, 11-34.

GÖnCÜOĞLU, M. C., TURhan, N., SEnTÜRK, K., ÖzCAn, A., Uysal, S. \& YAliniz, M. K. 2000. A geotraverse across northwestern Turkey: tectonic units of the Central Sakarya region and their tectonic evolution. In Tectonics and Magmatism in Turkey and the Surrounding Area (eds E. Bozkurt, J. A. Winchester \& J. D. A. Piper), pp. 139-161. Geological Society of London, Special Publication no. 173. 
533 GÖnCÜOĞLU, M. C., YALiniz, M. K., TeKin, U. K. \& TuRHAN, N. 2001. Petrology of Late 534 Berriasian-Late Hauterivian and Cenomanian oceanic basalts within the Central Sakarya 535 ophiolitic complex, NW Turkey: constraints for the evolution of the Izmir-Ankara oceanic 536 branch of Neotethys. Fourth International Turkish Geology Symposium (ITGS IV), Cfikfirova 537 University Adana (Turkey), 93.

538

GORIČAN, S. 1994. Jurassic and Cretaceous radiolarian biostratigraphy and sedimentary evolution of the Budva Zone (Dinarides, Montenegro). Mémoires de Géologie Lausanne 18, $5411-176$.

542

GÜngÖR, T., AKal, C., Özer, S., HasÖZBeK, A., SARI, B., \& MertZ-KraUs, R. 2018.

544

545

546

547

548

549

550

551

552

553

554

555

556

Kinematics and U-Pb zircon ages of the sole metamorphics of the Marmaris Ophiolite, Lycian Nappes, Southwest Turkey. International Geology Review, published online 23 July 2018. doi: 10.1080/00206814.2018.1498029.

Gürer, D., Plunder, A., Kirst, F., Corfu, F., Schmid, S. M., \& van Hinsbergen, D. J. J. 2018. A long-lived Late Cretaceous-Early Eocene extensional province in Anatolia? Structural evidence from the Ivriz Detachment, southern central Turkey. Earth Planetary Science Letters 481, 111-124.

\section{HatzipanAgiotou, K. 1987. Mikrofazies und fauna von karbonatgesteinen der} ophiolithischen Melange der südägäischen Inselbrücke. Newsletters on stratigraphy 18 (1), 41-50. 
HatZipanagiotou, K. 1988. Einbindung der obersten Einheit von Rhodos und Karpathos

(Griechenland) in der alpinischen Ophiolith-Gürtel. Neues Jahrbuch für Geologie und Paläontologie, Abhandlungen 176, 395-442.

HAtZIPANAgiOTOU, K. 1991. K-Ar dating of ophiolites from the Rhodes and Karpathos islands, Dodekanese, Greece. Geologica Balcanica 21, 69-76.

Jolivet, L., Rimmelé, G., Oberhänsli, R., Goffé, B. \& CANDAN, O. 2004. Correlation of synorogenic tectonic and metamorphic events in the Cyclades, the Lycian Nappes and the Menderes massif, geodynamic implications. Bulletin de la Société Géologique de France 175 (3), 217-238.

Jolivet, L., Faccenna, C., Huet, B., Labrousse, L., Le Pourhiet, L., Lacombe, O., Lecomte, E., Burov, E., Denele, Y., Brun, J.-P., Philippon, M., Paul, A., SAlaün, G., Karabulut, H., Piromallo, C., Monie, P., Gueydan, F., OKay, A., Oberhänsli, R., Pourteau, A., Augier, R., Gadenne, L. \& Driussi, O. 2013. Aegean tectonics: Strain localization, slab tearing and trench retreat. Tectonophysics 597-598, 1-33.

KoePKe, J., KreuZer, H. \& SeIDEL, E. 1985. Ophiolites in the Southern Aegean arc (Crete, Karpathos, Rhodes) - linking the ophiolite belts of the Hellenides and the Taurides. Ofioliti 10, 343-354.

KoepKe, J., Seidel, E. \& Kreuzer, H. 2002. Ophiolites on the Southern Aegean islands Crete, Karpathos and Rhodes: composition, geochronology and position within the ophiolite belts of the Eastern Mediterranean. Lithos 65 (1), 183-203. 
600

601

602

603

604

LiAti, A., Gebauer, D. \& FAnning, C.M. 2004. The age of ophiolitic rocks of the Hellenides (Vourinos, Pindos, Crete): first U-Pb ion micropobe (SHRIMP) zircon ages. Chemical Geology 207, 171-188.

MCDOUgALl, I., \& HARRISON, T.M. 1999. Geochronology and thermochronology by the 40Ar/39Ar method. New York, Oxford University Press, 269 pp.

MAFFIONE, M., \& VAN HinSBERGEN, D. J. J. 2018. Reconstructing plate boundaries in the Jurassic Neo-Tethys from the East and West Vardar Ophiolites (Greece and Serbia). Tectonics 37, 858-887.

MARTELli, A. 1916. Appunti geologici sull’Isola di Scarpanto. Bollettino della Società geologica italiana 35, 215-234.

Menant, A., JoliVet, L., VRIELYNCK, B. 2016. Kinematic reconstructions and magmatic evolution illuminating crustal and mantle dynamics of the eastern Mediterranean region since the late Cretaceous. Tectonophysics 675, 103-140.

O’DogherTy, L. 1994. Biochronology and paleontology of mid-Cretaceous radiolarians from Northern Apennines (Italy) and Betic Cordillera (Spain). Mémoires de Géologie Lausanne 21, $1-413$.

O’Dogherty, L., Carter, E.S., Dumitrica, P., Gorican, S., De Wever, P., Bandini, N., Baumgartner, P.O. \& MATsuOKA, A. 2009. Catalogue of Mesozoic radiolarian genera: Part 2. Jurassic-Cretaceous. Geodiversitas 31 (2), 271-356. 
OKAY, A. I., TANSEL, I. \& TÜYSÜZ, O. 2001. Obduction, subduction and collision as reflected in the Upper Cretaceous-Lower Eocene sedimentary record of western Turkey. Geological Magazine 138, 117-142.

PANTOPOULOS, G. \& ZELILIDIS, A. 2014. Eocene to early oligocene turbidite sedimentation in the SE Aegean (Karpathos Island, SE Greece): stratigraphy, facies analysis, nannofossil study, and possible hydrocarbon potential. Turkish Journal of Earth Sciences 23, 31-52.

PAPANIKOLAOU, D. 2013. Tectonostratigraphic models of the Alpine terranes and subduction history of the Hellenides. Tectonophysics 595-596, 1-24.

Parlak, O., Karaoglan, F., RizaOglu, T., KlÖtZli, U., Koller, F. \& Billor, Z. 2013. U$\mathrm{Pb}$ and ${ }^{40} \mathrm{Ar} /{ }^{39} \mathrm{Ar}$ Geochronology of the ophiolites and granitoids from the Tauride Belt: Implications for the evolution of the Inner Tauride Suture. Journal of Geodynamics 65, 2237.

Pessagno, E.A., JR. 1976. Radiolarian zonation and stratigraphy of the Upper Cretaceous portion of the Great Valley Sequence, California Coast Ranges. Micropaleontology, Special Publication no. 2, 1-95.

PeSSAGNO, E.A., JR. 1977. Lower Cretaceous radiolarian biostratigraphy of the Great Valley sequence and Franciscan Complex, California Coast Ranges. Cushman Foundation Foraminiferal Research Special Publication 15, 1-87.

Psimenos, S., Reppas, F., Mouzaki, A., Tassoula, N. \& Kodoni, O. 2017. Karpathos/Kasos map sheet 1:30 000. Terrain Editions, Athens. 
636 Robertson, A.H.F. 2002. Overview of the genesis and emplacement of Mesozoic ophiolites

637 in the Eastern Mediterranean Tethyan region. Lithos 65, 1-67.

638

639 RoBertson, A.H.F. \& WoOdCOCK, N.H. 1982. Sedimentary history of the south-western

640 segment of the Mesozoic-Tertiary Antalya continental margin, south-western Turkey.

641 Eclogae Geologicae Helveticae 75, 517-562.

642

643

Robertson, A. H. F. \& Pickett, E. A. 2000. Palaeozoic-Early Tertiary Tethyan evolution of 644 mélanges, rift and passive margin units in the Karaburun Peninsula (western Turkey) and

645 Chios Island (Greece). In Tectonics and Magmatism in Turkey and the Surrounding Area (eds 646 E. Bozkurt, J. A. Winchester \& J. D. A. Piper), pp. 25-42. Geological Society of London, 647 Special Publication no. 173.

648

649

650

Robertson, A. H. F., Ustaömer, T., Pickett, E. A., Collins, A. S., Andrew, T. \& Dixon, J. E. 2004. Testing models of Late Palaeozoic-Early Mesozoic orogeny in Western Turkey: support for an open-Tethys model. Journal of the Geological Society 161, 201-511.

652

653

Robertson, A.H.F., PArlaK, O., Ustä̈mer, T. 2012. Overview of the Palaeozoic-Neogene 654 evolution of Neotethys in the Eastern Mediterranean region (southern Turkey, Cyprus, Syria) Petroleum Geoscience 18 (4), 381-404.

656

657 Roche, V., Conand, C., Jolivet, L., \& Augier, R. 2018. Tectonic evolution of Leros Island 658 (Dodecanese, Greece) and correlations between the Aegean Domain and the Menderes 659 Massif. Journal of the Geological Society 175, 836-849. 
663

664

665

666

667

668

669

670

671

672

673

674

675

676

677

678

679

680

681

682

683

684

685

686

Royden, L. \& FACCENNA, L. 2018. Subduction Orogeny and the Late Cenozoic Evolution of the Mediterranean Arcs. Annual Review of Earth and Planetary Sciences 46, 261-289.

SchetTino, A. \& Turco, E. 2011. Tectonic history of the western Tethys since the Late Triassic. Geological Society of America Bulletin 123 (1/2), 89-105.

SMITH, A.G. 2006. Tethyan ophiolite emplacement, Africa to Europe motions, and Atlantic spreading. Geological Society London, Special Publication 260 (1), 11-34.

StAmPfli, G., ChAMPOD, E. \& VANDELLI, A. 2010. Tectonostratigraphy and Plate Tectonics of Crete. Field Guide, University of Lausanne, 64 p.

VAn Hinsbergen, D.J.J., ZaChariasse, W.J., Wortel, M.J.R. \& MEUlenKAMP, J.E. 2005.

Nappe stacking resulting from subduction of oceanic and continental lithosphere below

Greece. Geology 33 (4), 325-328.

VAn HinsBergen, D.J.J., KAYMAKÇI, N., SPAKMAN, W. \& TORSVIK, T.H. 2010. Reconciling the geological history of western Turkey with plate circuits and mantle tomography. Earth Planetary Science Letters 297, 674-686.

VinAsSa De Regny, P. 1901. Radiolari Cretacei dell'Isola di Karpathos. Memoria Accademia Scienze Bologna, serie 5, 9, 497-512.

YILMAZ, P.O. 1984. Fossil and K-Ar data for the age of the Antalya Complex, S.W. Turkey. In The Geological Evolution of the Eastern Mediterranean (eds J.E. Dixon \& A.H.F. Robertson), pp. 335- 348. Geological Society London, Special Publication no. 17. 
688 Zachariasse, W.J., VAn HinsBergen, D.J.J. \& Fortuin, A.R. 2008. Mass wasting and uplift 689 on Crete and Karpathos (Greece) during the early Pliocene related to beginning of south 690 Aegean left-lateral, strike slip tectonics. Geological Society of America Bulletin 120, 976691993.

692

693

694

695

696

697

698

699

700

701

702

703

704

705

706

707

708

709

710

711

\section{Figure captions}

Figure 1 (Colour online). Structural map of the southern Aegean region with location of the island of Karpathos (black frame) and the distribution of ophiolites in southern Greece and western Turkey. Compiled from Bornovas \& Rontogianni-Tsiabaou (1983), Jolivet et al. (2004, 2013), van Hinsbergen et al. (2005, 2010), Stampfli, Champod \& Vandelli (2010), Ersoy et al. (2014), and Gürer et al. (2018). The ‘eastern’ and ‘western’ ophiolite regions refer to the classification by Robertson (2002). IAE: Izmir-Ankara-Erzincan Suture Zone.

Figure 2. (a) Geological and structural map of Karpathos (modified after Aubouin, Bonneau \& Davidson, 1976). (b) Geological map of the Lastos area and location of the radiolarian localities KAL01 (section ‘North Lastos road'), KAL02 and KAL03 (section 'Hill 730 m’ outlined by a white band). Topography from the Karpathos-Kasos map sheet 1:30 000 (Psimenos et al. 2017). Geology based on Christodoulou (1968), Davidson-Monett (1974), Aubouin, Bonneau \& Davidson (1976), and personal field observations. (c) Geological map of the Menetes area and location of the radiolarian locality KAM01. Topography from the Karpathos-Kasos map sheet 1:30 000 (Psimenos et al. 2017). Geology from the Karpathos map sheet (Christodoulou, 1968). 
Figure 3. (Colour online) (a) Synthetic lithostratigraphic column of the Xindothio Unit

713 succession (modified after Aubouin, Bonneau \& Davidson, 1976). Basal radiolarites overlying mafic/ultramafic rocks are presently dated as Aptian (this study) instead of Berriasian (Aubouin, Bonneau \& Davidson, 1976). Isotopic ages are from Cohen et al. (2013, updated 2018). Dotted lines (left): probable positions of stage boundaries based on biochronological data; red line: thrust fault at the base of mafic/ultramafic rocks; dotted lines (right): boundaries between subunits. (b) Sections in the Lastos and Menetes areas and stratigraphic positions of the radiolarian samples.

Figure 4. (Colour online) Schematic cross-section of the south Lastos area including section 'Hill 730 m' and position of samples KAL02 and KAL03 close to the contact with mafic/ultramafic rocks (modified after Aubouin, Bonneau \& Davidson, 1976). Note that the Xindothio Unit is structurally situated above the dolomitic limestones of the Kalilimni Unit but underwent Cenozoic extension and normal faulting visible in the southwestern part of the section.

Figure 5. Field views of the studied Karpathos units and localities (see Fig. 2b for locations of photographs). (a) Overview of section 'Hill 730 m' in Lastos (Figs. 2b, 3b, 4) and subunits within the Xindothio Unit (Fig. 3); in the distance towards the west: parautochthonous limestone exposures of Kalilimni Unit; Mount Kalilimni (1215 m) is the highest point on the island. (b) Exposure of serpentinite (white arrows) overlain by the red radiolarite-pink limestone subunit along the north Lastos road (Fig. 2b). White dashed line: contact between ultramafic and sedimentary rocks. White dotted lines: bedding of radiolarite and pink limestone, parallel to the contact between ultramafic and sedimentary rocks. (c) Close-up of the contact between serpentinite and radiolarite (dashed line) along the north Lastos road near locality KAL01 (Fig. 2b). (d) Pink limestone and chert nodules (white arrows) exposed in the 
middle part of section ‘Hill 730 m’ (total thickness $1 \mathrm{~m}$ ). (e) Close-up of thick radiolarite beds at the base of section 'Hill 730 m' (Lastos, Figs. 2b, 3, 4). (f) Exposure of the Lastos conglomerate (Eocene) displaying a variety of pebbles of radiolarite (white arrows), serpentinite (yellow arrows) and limestones from the underlying Kalilimni and Xindothio units.

Figure 6. Scanning electron microphotographs (SEM) of radiolarian taxa from Lastos (KAL) and Menetes (KAM). For each sample: age and radiolarian assemblage. For each picture: radiolarian taxon, scale length.

- Sample KAL03 (Turonian); 1. Pseudodictyomitra pseudomacrocephala (SQUINABOL) $(210 \mu \mathrm{m}) ;$ 2. Dictyomitra napaensis PESSAGNO (200 $\mu \mathrm{m})$; 3. Dictyomitra montisserei (SQUINABOL) $(220 \mu \mathrm{m}) ;$ 4. Stichomitra communis (SQUINABOL) $(190 \mu \mathrm{m}) ; 5$. Afens sp. (200 $\mu \mathrm{m}) ;$ 6. Crucella cachensis PESSAGNO (180 $\mu \mathrm{m}) ;$ 7. Patellula verteroensis (PESSAGNO) $(160 \mu \mathrm{m})$.

- Sample KAL01 (Aptian); 8. Cenodiscaella sphaeroconus (RÜST) (200 $\mu \mathrm{m}) ; 9$. Homoeoparonaella sp. cf. speciosa (PARONA) (320 $\mu \mathrm{m}) ; 10$. Crucella messinae PESSAGNO (240 $\mu \mathrm{m}) ; 11$. Crucella euganea SQUINABOL (240 $\mu \mathrm{m}) ; 12$. Ultranapora sp. cf. durhami PESSAGNO (140 $\mu \mathrm{m})$; 13. Pseudodictyomitra lodogaensis PESSAGNO (180 $\mu \mathrm{m}) ; 14$. Dictyomitra montisserei (SQUINABOL) $(180 \mu \mathrm{m}) ; 15$. Xitus sp. aff. spicularius (ALIEV) $(210 \mu \mathrm{m}) ; 16$. Archaeodictyomitra gracilis (SQUINABOL) $(200 \mu \mathrm{m}) ; 17$. Archaeodictyomitra gracilis (SQUINABOL) $(180 \mu \mathrm{m}) ; 18$. Hiscocapsa asseni (TAN) (120 $\mu \mathrm{m})$; 19. Hiscocapsa grutterinki (TAN) $(150 \mu \mathrm{m})$. - Sample KAL02 (early-middle Albian); 20. Obeliscoites sp. cf. perspicuus (SQUINABOL) (180 $\mu \mathrm{m}) ; 21$. Xitus spicularius (ALIEV) $(190 \mu \mathrm{m}) ; 22$. Dactyliosphaera lepta FOREMAN (200 $\mu \mathrm{m})$; 23. Dactyliosphaera sp. cf. lepta FOREMAN (200 $\mu \mathrm{m}) ; 24$. Mesosaturnalis sp. 
763

764

765

766

767

768

769

770

771

772

773

774

775

776

777

778

779

780

781

782

783

784

785

786

787

$(190 \mu \mathrm{m}) ; 2$ 25. Hexapyramis sp. cf. precedis JUD (190 $\mu \mathrm{m})$; 26. Cyclastrum satoi

(TUMANDA) $(180 \mu \mathrm{m})$.

- Sample KAM01 (middle Albian); 27. Cenodiscaella tuberculatum (DUMITRICA) (160

$\mu \mathrm{m}) ;$ 28. Staurosphaeretta sp. $(130 \mu \mathrm{m}) ; 29$. Thanarla brouweri (TAN) $(120 \mu \mathrm{m}) ; 30$.

Archaeospondoprumum renaensis PESSAGNO (180 $\mu \mathrm{m}) ; 31$. Distylocapsa micropora

(SQUINABOL) $(180 \mu \mathrm{m})$.

Figure 7. Schematic paleogeographic map of western Neotethyan basins in the Cretaceous.

Compiled from Barrier \& Vrielynck (2008), Robertson, Parlak \& Ustaömer (2012), Menant et al. (2016), Barrier et al. (2018), Maffione \& van Hinsbergen (2018). Star: hypothetical position of Karpathos ophiolite prior to obduction. Note that the ophiolites and the tectonic nappes depicted in the diagram have been emplaced diachronously: they just indicate the initial locations and relationships to the surrounding oceanic basins.

Figure 8. (a) Map of the Aegean region prior to the complete southward migration of the Aegean fore-arc during the Neogene (modified after Garfunkel, 2004). The map shows the position of the ophiolites and the extensions of the Pindos and Lycian nappes, which have been proposed as potential sources for the ophiolite-bearing units of Crete, Karpathos, and Rhodes. A-B: cross-section shown in (b). Isotopic ages, Crete: Koepke, Seidel \& Kreuzer (2002); Liati, Gebauer \& Fanning (2004). Karpathos and Rhodes: Koepke, Seidel \& Kreuzer (2002). Southwestern Turkey: Dilek et al. (1999); Güngör et al. (2018) (see references for age ranges, error margins and local distribution). Age of radiolarites, Crete: Stampfli, Champod \& Vandelli (2010); Turkey: Danelian et al. (2006); Karpathos: this study. IAE:

Izmir-Ankara-Erzincan Suture Zone. (b) Cross-section A-B (Fig. 8a) from the Eastern Mediterranean Basin to the Izmir-Ankara-Erzincan Suture Zone (modified after van 
788 Hinsbergen et al. 2010), illustrating the southward thrusting of the Lycian Nappes and related 789 ophiolites over Rhodes and Karpathos.

790 
791 Table 1. K-Ar isotopic ages in the Lastos and Menetes areas (Koepke, Seidel \& Kreuzer,

792 2002) and correlation with geological stages (Cohen et al. 2013, updated 2018).

793

794

\begin{tabular}{ccccc} 
& K-Ar age (Ma) & Error (Ma) & Lower limit & Upper limit \\
\hline Lastos & 83.1 & \pm 1.6 & $\begin{array}{c}84.7 \\
\text { middle Santonian }\end{array}$ & $\begin{array}{c}81.5 \\
\text { early Campanian }\end{array}$ \\
\cline { 2 - 5 } & 81.2 & \pm 1.6 & $\begin{array}{c}82.8 \\
\text { early Campanian }\end{array}$ & $\begin{array}{c}79.6 \\
\text { middle Campanian }\end{array}$ \\
\hline Menetes & 91.9 & \pm 3.5 & $\begin{array}{c}95.4 \\
\text { late Cenomanian }\end{array}$ & $\begin{array}{c}88.4 \\
\text { early Coniacian }\end{array}$ \\
\cline { 2 - 5 } & 95.3 & \pm 4.2 & $\begin{array}{c}99.5 \\
\text { early Cenomanian }\end{array}$ & $\begin{array}{c}91.1 \\
\text { middle Turonian }\end{array}$ \\
\cline { 2 - 5 } & 88.8 & \pm 5 & $\begin{array}{c}93.8 \\
\text { basal Turonian }\end{array}$ & $\begin{array}{c}83.8 \\
\text { late Santonian }\end{array}$ \\
\hline
\end{tabular}

795 
Table 2. Geographic coordinates of radiolarian samples from Karpathos.

797

\begin{tabular}{|c|c|c|c|}
\hline \multirow[t]{3}{*}{ Lastos } & KAL01 & N 35 34' 51.90" & E $27^{\circ} 08^{\prime} 35.96 "$ \\
\hline & KAL02 & N 35³ 34' 16.08" & Е $27^{\circ} 08^{\prime} 26.14^{\prime \prime}$ \\
\hline & KAL03 & N 35³4' 20.66" & E $27^{\circ} 08^{\prime} 30.57^{\prime \prime}$ \\
\hline Menetes & KAM01 & N 35² 29' 28.59" & Е 270 09' 3.84" \\
\hline
\end{tabular}

798 


\begin{tabular}{|c|c|c|c|c|}
\hline Taxa & KAL01 & KAL02 & KAL03 & KAM01 \\
\hline Afens sp. & & & $\mathrm{x}$ & \\
\hline Alievium sp. & & $\mathrm{x}$ & & \\
\hline Alievum sp. cf. superbum (SQUINABOL) & & & $\mathrm{x}$ & \\
\hline Archaeodictyomitra gracilis (SQUINABOL) & $\mathrm{x}$ & & & \\
\hline Archaeospongoprunum renaensis PESSAGNO & & & & $\mathrm{x}$ \\
\hline Archaeospongoprunum sp. & & & $\mathrm{x}$ & \\
\hline Cenodiscaella sphaeroconus (RÜST) & $\mathrm{x}$ & & & \\
\hline Cenodiscaella tuberculatum (DUMITRICA) & & & & $\mathrm{x}$ \\
\hline Crucella cachensis PESSAGNO & & & $\mathrm{x}$ & \\
\hline Crucella euganea SQUINABOL & $\mathrm{x}$ & & & \\
\hline Crucella messinae PESSAGNO & $\mathrm{x}$ & $\mathrm{x}$ & & \\
\hline Cyclastrum satoi (TUMANDA) & & $\mathrm{x}$ & & \\
\hline Dactyliosphaera lepta FOREMAN & & $\mathrm{x}$ & & \\
\hline Dictyomitra montisserei (SQUINABOL) & $\mathrm{x}$ & & $\mathrm{x}$ & \\
\hline Dictyomitra napaensis PESSAGNO & & & $\mathrm{x}$ & \\
\hline Distylocapsa micropora SQUINABOL & & & & $\mathrm{x}$ \\
\hline Falsocromyodrymus sp. & & & $\mathrm{x}$ & \\
\hline Hexapyramis sp. cf. precedis JUD & & $\mathrm{x}$ & & \\
\hline Hiscocapsa asseni (TAN) & $\mathrm{x}$ & & & \\
\hline Hiscocapsa grutterinki (TAN) & $\mathrm{x}$ & & & \\
\hline Homoeoparonaella sp. cf. speciosa (PARONA) & $\mathrm{x}$ & & & \\
\hline Mesosaturnalis levis (DONOFRIO \& MOSTLER) & & $\mathrm{x}$ & & \\
\hline Mesosaturnalis sp. & $\mathrm{x}$ & & & \\
\hline Obeliscoites sp. cf. perspicuus (SQUINABOL) & & $\mathrm{x}$ & & \\
\hline Paronaella sp. & $\mathrm{x}$ & & & \\
\hline Patellula verteroensis (PESSAGNO) & & & $\mathrm{x}$ & \\
\hline Pseudocrucella sp. aff. kubischa EMPSON-MORIN & $\mathrm{x}$ & & & \\
\hline Pseudodictyomitra lodogaensis PESSAGNO & $\mathrm{x}$ & & & $\mathrm{x}$ \\
\hline Pseudodictyomitra pseudomacrocephala (SQUINABOL) & & & $\mathrm{x}$ & \\
\hline Pseudoeucyrtis (?) fusus JUD & $\mathrm{x}$ & & & \\
\hline Staurosphaeretta sp. & & & & $\mathrm{x}$ \\
\hline Stichomitra communis (SQUINABOL) & $\mathrm{x}$ & & $\mathrm{x}$ & \\
\hline Thanarla brouweri (TAN) & & & & $\mathrm{x}$ \\
\hline Triactoma sp. & & & & $\mathrm{x}$ \\
\hline Ultranapora sp. cf. durhami PESSAGNO & $\mathrm{x}$ & & & \\
\hline Xitus sp. aff. spicularius (ALIEV) & $\mathrm{x}$ & & & \\
\hline Xitus spicularius (ALIEV) & & $\mathrm{x}$ & & \\
\hline
\end{tabular}




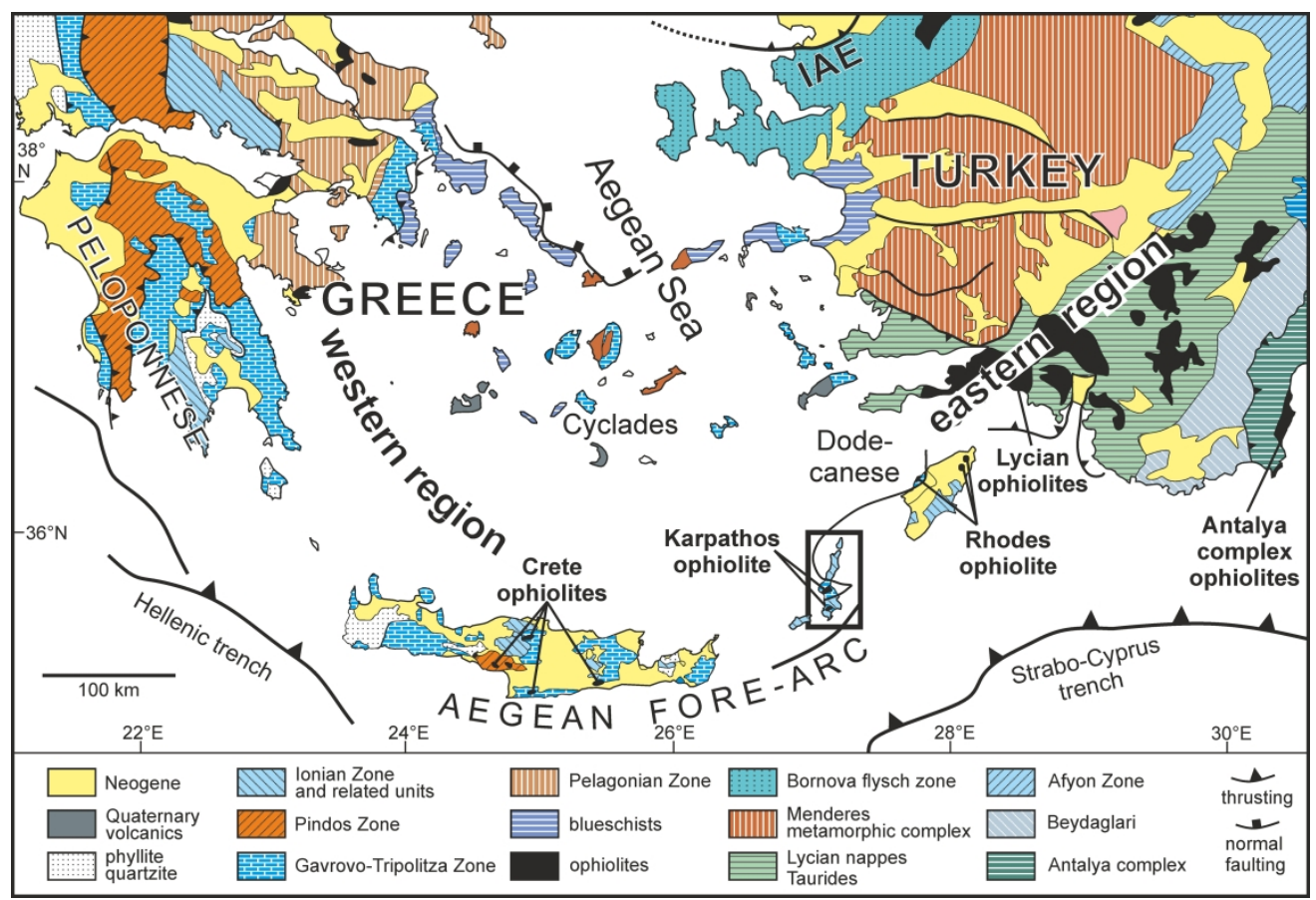

Figure 1 (Colour online). Structural map of the southern Aegean region with location of the island of Karpathos (black frame) and the distribution of ophiolites in southern Greece and western Turkey. Compiled from Bornovas \& Rontogianni-Tsiabaou (1983), Jolivet et al. (2004, 2013), van Hinsbergen et al. (2005, 2010), Stampfli, Champod \& Vandelli (2010), Ersoy et al. (2014), and Gürer et al. (2018). The 'eastern' and 'western' ophiolite regions refer to the classification by Robertson (2002). IAE: Izmir-Ankara-Erzincan Suture Zone. 


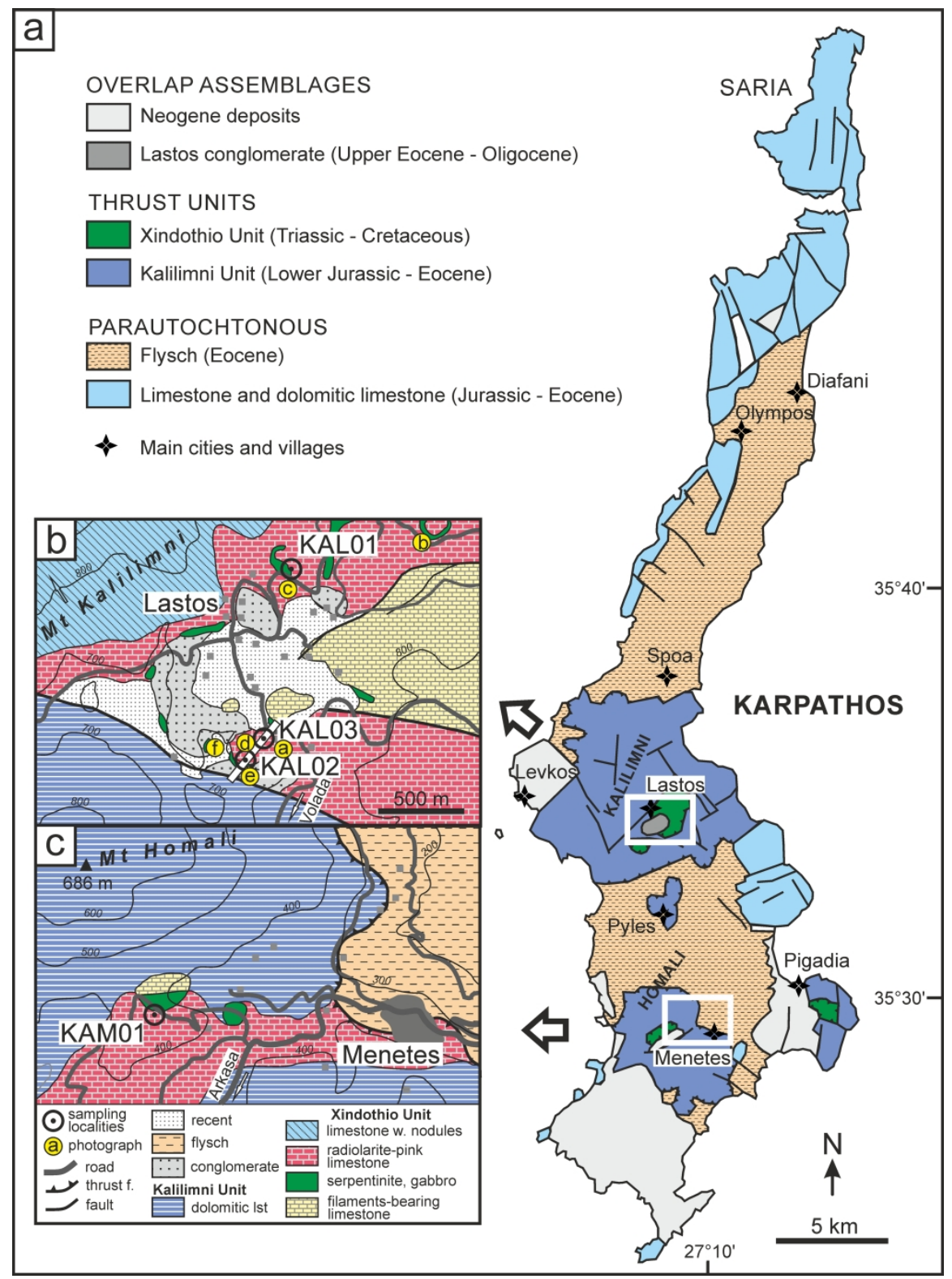

Figure 2. (a) Geological and structural map of Karpathos (modified after Aubouin, Bonneau \& Davidson, 1976). (b) Geological map of the Lastos area and location of the radiolarian localities KAL01 (section 'North Lastos road'), KAL02 and KAL03 (section 'Hill $730 \mathrm{~m}^{\prime}$ outlined by a white band). Topography from the Karpathos-Kasos map sheet 1:30 000 (Psimenos et al. 2017). Geology based on Christodoulou (1968), Davidson-Monett (1974), Aubouin, Bonneau \& Davidson (1976), and personal field observations. (c) Geological map of the Menetes area and location of the radiolarian locality KAM01. Topography from the Karpathos-Kasos map sheet 1:30 000 (Psimenos et al. 2017). Geology from the Karpathos map sheet (Christodoulou, 1968). 


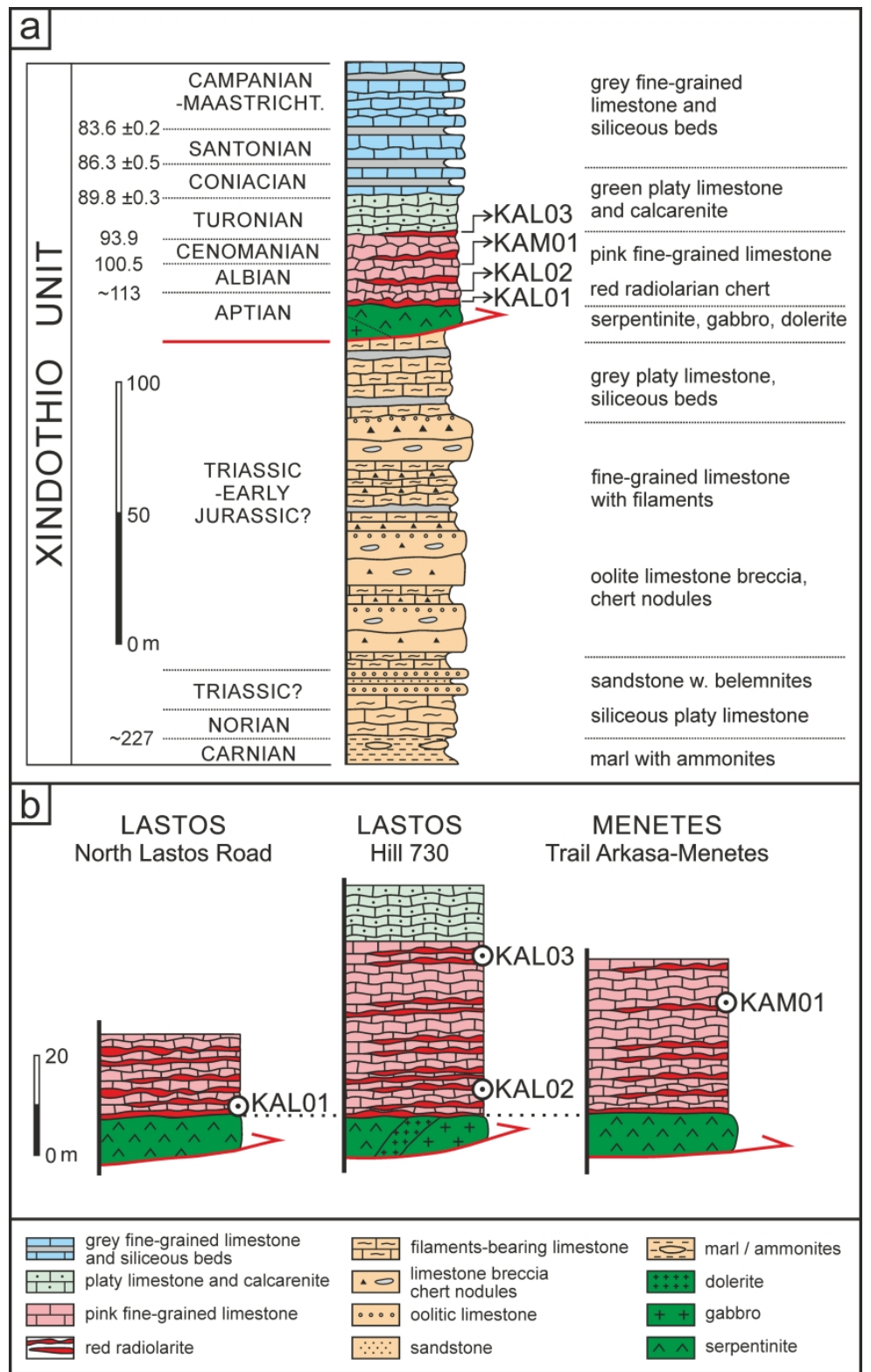

Figure 3. (Colour online) (a) Synthetic lithostratigraphic column of the Xindothio Unit succession (modified after Aubouin, Bonneau \& Davidson, 1976). Basal radiolarites overlying mafic/ultramafic rocks are presently dated as Aptian (this study) instead of Berriasian (Aubouin, Bonneau \& Davidson, 1976). Isotopic ages are from Cohen et al. (2013, updated 2018). Dotted lines (left): probable positions of stage boundaries based on biochronological data; red line: thrust fault at the base of mafic/ultramafic rocks; dotted lines (right): boundaries between subunits. (b) Sections in the Lastos and Menetes areas and stratigraphic positions of the radiolarian samples. 


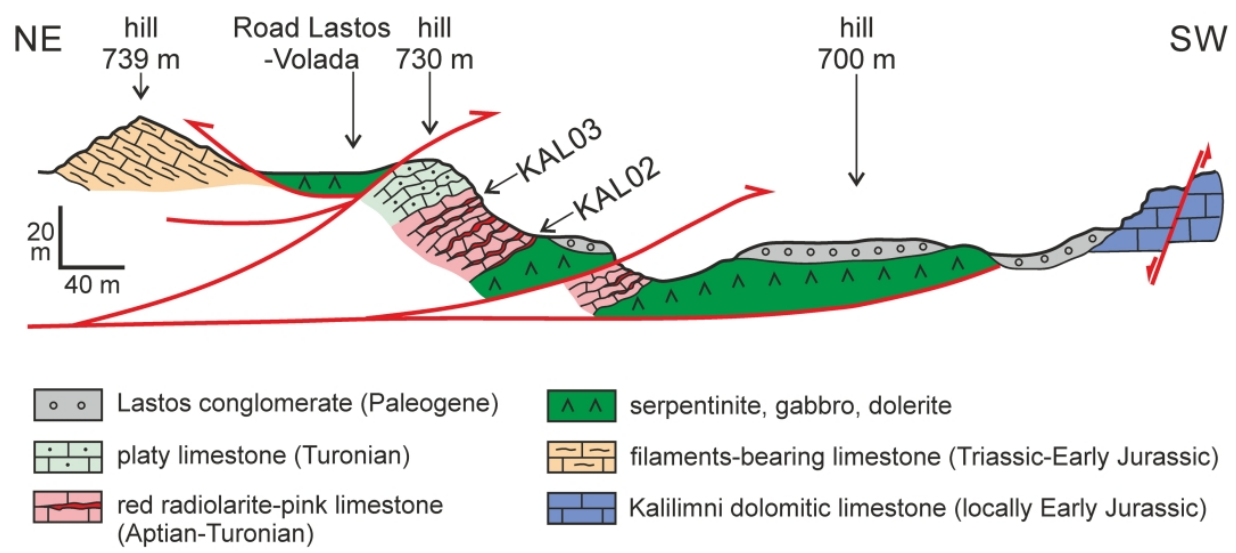

Figure 4. (Colour online) Schematic cross-section of the south Lastos area including section 'Hill $730 \mathrm{~m}$ ' and position of samples KAL02 and KAL03 close to the contact with mafic/ultramafic rocks (modified after Aubouin, Bonneau \& Davidson, 1976). Note that the Xindothio Unit is structurally situated above the dolomitic limestones of the Kalilimni Unit but underwent Cenozoic extension and normal faulting visible in the southwestern part of the section.

$165 \times 75 \mathrm{~mm}(600 \times 600 \mathrm{DPI})$ 

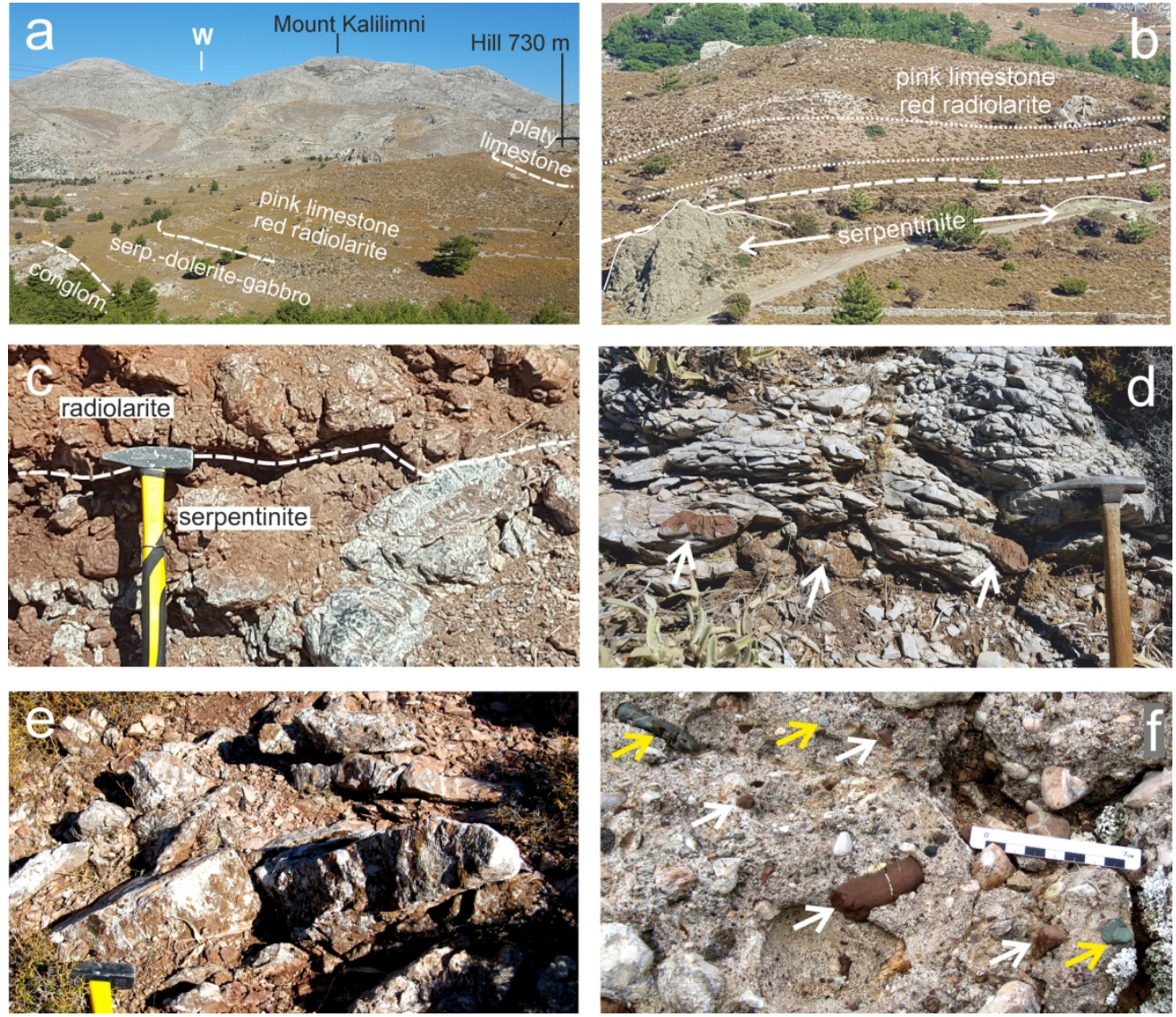

Figure 5. Field views of the studied Karpathos units and localities (see Fig. $2 b$ for locations of photographs). (a) Overview of section 'Hill $730 \mathrm{~m}^{\prime}$ in Lastos (Figs. 2b, 3b, 4) and subunits within the Xindothio Unit (Fig. $3)$; in the distance towards the west: parautochthonous limestone exposures of Kalilimni Unit; Mount Kalilimni $(1215 \mathrm{~m})$ is the highest point on the island. (b) Exposure of serpentinite (white arrows) overlain by the red radiolarite-pink limestone subunit along the north Lastos road (Fig. $2 \mathrm{~b}$ ). White dashed line: contact between ultramafic and sedimentary rocks. White dotted lines: bedding of radiolarite and pink limestone, parallel to the contact between ultramafic and sedimentary rocks. (c) Close-up of the contact between serpentinite and radiolarite (dashed line) along the north Lastos road near locality KAL01 (Fig. 2b). (d) Pink

limestone and chert nodules (white arrows) exposed in the middle part of section 'Hill 730 m' (total

thickness $1 \mathrm{~m}$ ). (e) Close-up of thick radiolarite beds at the base of section 'Hill $730 \mathrm{~m}^{\prime}$ (Lastos, Figs. 2b, 3, 4). (f) Exposure of the Lastos conglomerate (Eocene) displaying a variety of pebbles of radiolarite (white arrows), serpentinite (yellow arrows) and limestones from the underlying Kalilimni and Xindothio units. 


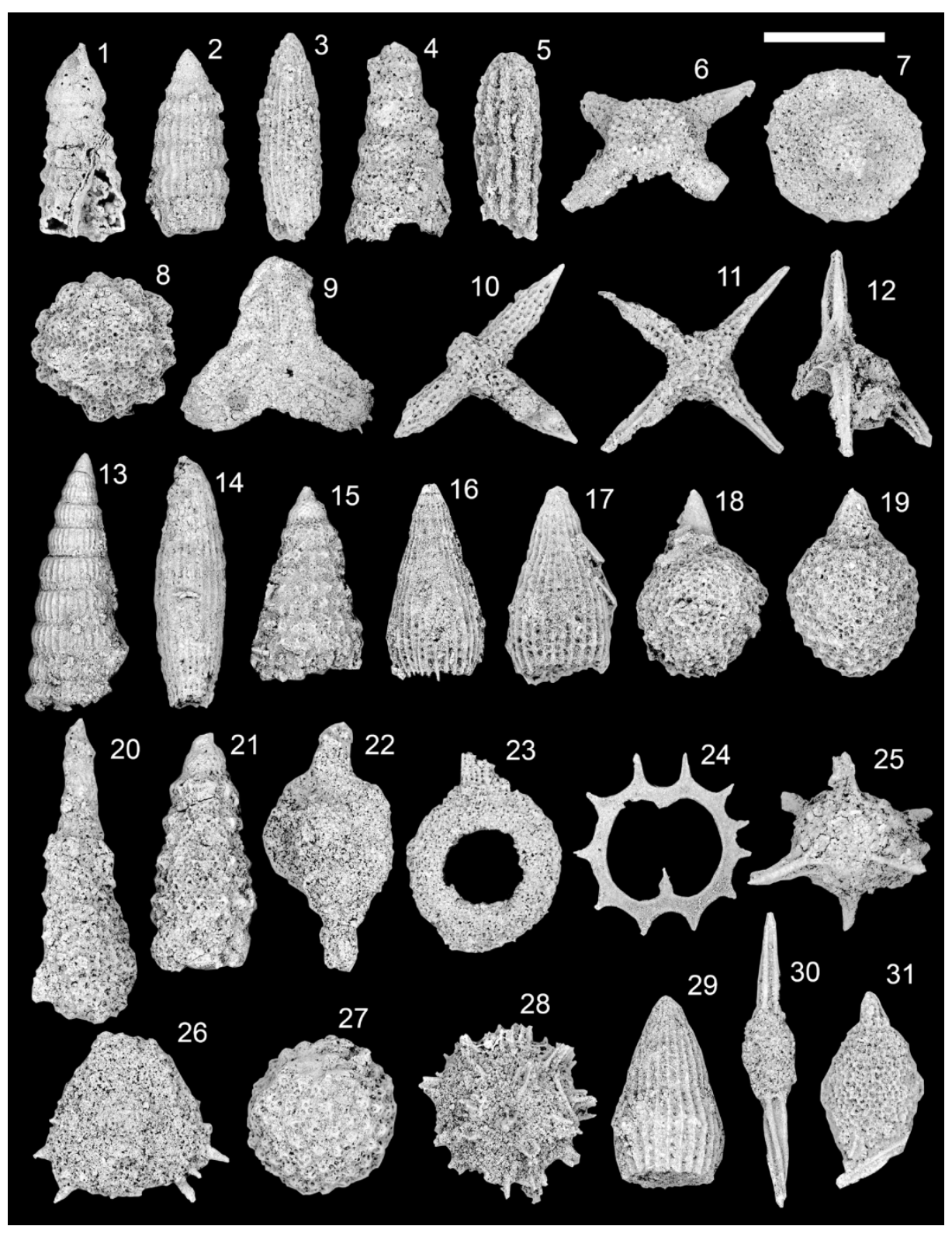

Figure 6. Scanning electron microphotographs (SEM) of radiolarian taxa from Lastos (KAL) and Menetes (KAM). For each sample: age and radiolarian assemblage. For each picture: radiolarian taxon, scale length.

Sample KAL03 (Turonian): 1. Pseudodictyomitra pseudomacrocephala (SQUINABOL) $(210 \mu \mathrm{m}) ; 2$.

Dictyomitra napaensis PESSAGNO $(200 \mu \mathrm{m}) ; 3$. Dictyomitra montisserei (SQUINABOL) $(220 \mu \mathrm{m}) ; 4$.

Stichomitra communis (SQUINABOL) $(190 \mu \mathrm{m}) ;$ 5. Afens sp. $(200 \mu \mathrm{m}) ;$ 6. Crucella cachensis PESSAGNO

$(180 \mu \mathrm{m}) ; 7$. Patellula verteroensis (PESSAGNO) $(160 \mu \mathrm{m})$. Sample KAL01 (Aptian): 8. Cenodiscaella sphaeroconus (RÜST) $(200 \mu \mathrm{m}) ; 9$. Homoeoparonaella sp. cf. speciosa (PARONA) (320 $\mu \mathrm{m}) ; 10$. Crucella messinae PESSAGNO $(240 \mu \mathrm{m}) ; 11$. Crucella euganea SQUINABOL $(240 \mu \mathrm{m}) ; 12$. Ultranapora sp. cf. durhami PESSAGNO $(140 \mu \mathrm{m}) ; 13$. Pseudodictyomitra lodogaensis PESSAGNO (180 $\mu \mathrm{m}) ; 14$. Dictyomitra montisserei (SQUINABOL) $(180 \mu \mathrm{m}) ; 15$. Xitus sp. aff. spicularius (ALIEV) $(210 \mu \mathrm{m}) ; 16$. Archaeodictyomitra gracilis (SQUINABOL) $(200 \mu \mathrm{m}) ; 17$. Archaeodictyomitra gracilis (SQUINABOL) $(180 \mu \mathrm{m}) ; 18$. Hiscocapsa asseni (TAN) $(120 \mu \mathrm{m}) ; 19$. Hiscocapsa grutterinki (TAN) $(150 \mu \mathrm{m})$. Sample KAL02 (early-middle Albian): 20. Obeliscoites sp. cf. perspicuus (SQUINABOL) $(180 \mu \mathrm{m}) ; 21$. Xitus spicularius (ALIEV) $(190 \mu \mathrm{m}) ; 22$. Dactyliosphaera lepta FOREMAN $(200 \mu \mathrm{m}) ; 23$. Dactyliosphaera sp. cf. lepta FOREMAN $(200 \mu \mathrm{m}) ; 24$. 
Mesosaturnalis sp. $(190 \mu \mathrm{m}) ; 25$. Hexapyramis sp. cf. precedis JUD $(190 \mu \mathrm{m}) ; 26$. Cyclastrum satoi (TUMANDA) $(180 \mu \mathrm{m})$. Sample KAM01 (middle Albian): 27. Cenodiscaella tuberculatum (DUMITRICA) (160 $\mu \mathrm{m}) ; 28$. Staurosphaeretta sp. $(130 \mu \mathrm{m}) ; 29$. Thanarla brouweri (TAN) $(120 \mu \mathrm{m}) ; 30$.

Archaeospondoprumum renaensis PESSAGNO $(180 \mu \mathrm{m}) ; 31$. Distylocapsa micropora (SQUINABOL) (180 $\mu \mathrm{m})$.

$167 \times 217 \mathrm{~mm}(300 \times 300 \mathrm{DPI})$ 


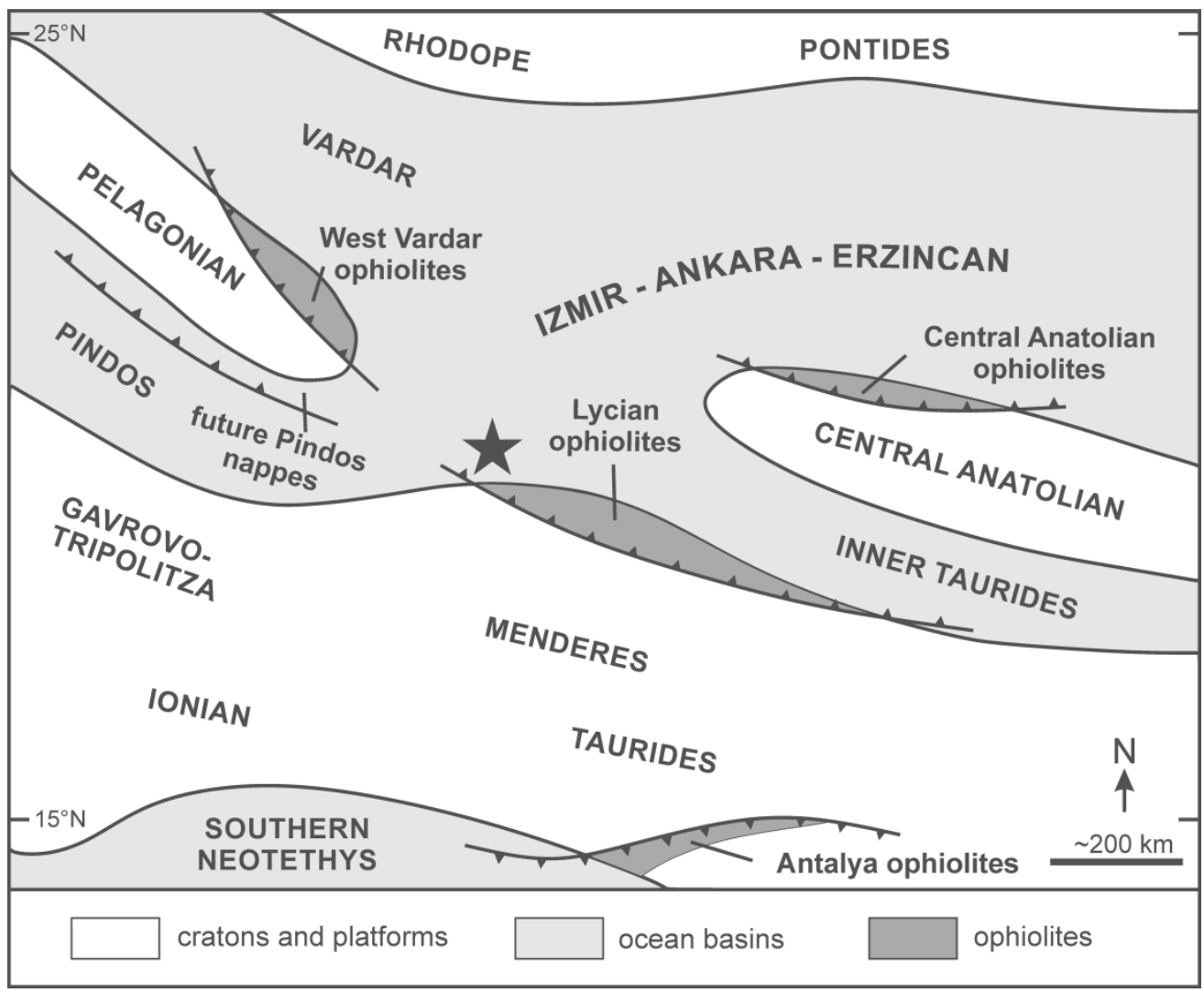

Figure 7. Schematic paleogeographic map of western Neotethyan basins in the Cretaceous. Compiled from Barrier \& Vrielynck (2008), Robertson, Parlak \& Ustaömer (2012), Menant et al. (2016), Barrier et al. (2018), Maffione \& van Hinsbergen (2018). Star: hypothetical position of Karpathos ophiolite prior to obduction. Note that the ophiolites and the tectonic nappes depicted in the diagram have been emplaced diachronously: they just indicate the initial locations and relationships to the surrounding oceanic basins. 


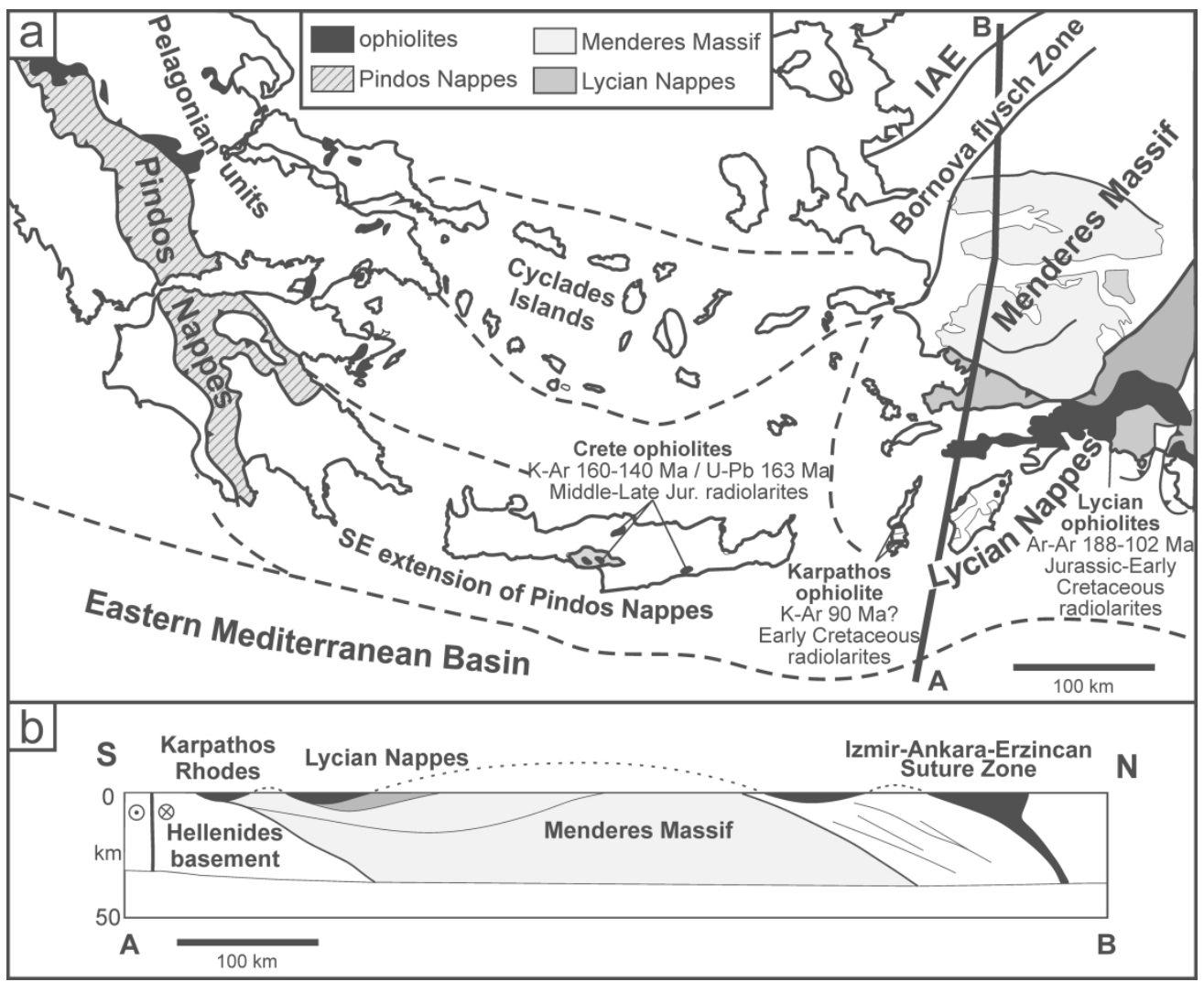

Figure 8. (a) Map of the Aegean region prior to the complete southward migration of the Aegean fore-arc during the Neogene (modified after Garfunkel, 2004). The map shows the position of the ophiolites and the extensions of the Pindos and Lycian nappes, which have been proposed as potential sources for the ophiolite-bearing units of Crete, Karpathos, and Rhodes. A-B: cross-section shown in (b). Isotopic ages, Crete: Koepke, Seidel \& Kreuzer (2002); Liati, Gebauer \& Fanning (2004). Karpathos and Rhodes: Koepke, Seidel \& Kreuzer (2002). Southwestern Turkey: Dilek et al. (1999); Güngör et al. (2018) (see references for age ranges, error margins and local distribution). Age of radiolarites, Crete: Stampfli, Champod \& Vandelli (2010); Turkey: Danelian et al. (2006); Karpathos: this study. IAE: Izmir-Ankara-Erzincan Suture Zone. (b) Cross-section A-B (Fig. 8a) from the Eastern Mediterranean Basin to the Izmir-Ankara-Erzincan Suture Zone (modified after van Hinsbergen et al. 2010), illustrating the southward thrusting of the Lycian Nappes and related ophiolites over Rhodes and Karpathos. 